ECOLOGY AND SOCIETY

Home | Archives | About | Login | Submissions | Notify | Contact | Search

ES HOME > VOL. 3, NO. 1 > ART. 9

Copyright (C) 1999 by The Resilience Alliance-

Correct format for citing this article:

Shindler, B., and K. Aldred Cheek. 1999. Integrating citizens in adaptive management: a propositional analysis. Conservation Ecology 3(1): 9. [online] URL: http://www.consecol.org/vol3/iss1/art9/

Research, part of Special Feature on Adaptive Management

\title{
Integrating Citizens in Adaptive Management: A Propositional Analysis
}

Bruce Shindler $^{1}$ and Kristin Aldred Cheek ${ }^{2}$

${ }^{1}$ Oregon State University; ${ }^{2}$ University of Montana

- Abstract

- Introduction

- Background

- Research Approach

- Propositions for Integrating Citizens in Adaptive Management

- Proposition 1: Open and inclusive public processes enjoy increased support

- Proposition 2: Skilled leadership and interactive forums contribute to long-term relationships among participants

- Proposition 3: Innovation and flexibility improve the quality of decisions

- Proposition 4: Early and continuous involvement improves public understanding of the issues and managers understanding of participant perspectives

- Proposition 5: Efforts that result in tangible outcomes demonstrate accountability and build ownership among those involved

- Proposition 6: Incorporating citizens ideas and experiences in decisions builds trust in natural resource institutions

- Conclusion

- Responses to this Article

- Acknowledgments

- Literature Cited

\begin{abstract}
Lee has advocated for the use of civic science in the implementation of adaptive management experiments, noting that people and political processes are central features of adaptive approaches to land management. This paper explores the growing relationship between the public and forest management agencies, and uses a propositional analysis to guide methods for integrating citizens into adaptive management situations. Important characteristics are organized and discussed in six thematic areas. Citizen-agency interactions are more effective when (1) they are open and inclusive, (2) they are built on skilled leadership and interactive forums, (3) they include innovative and flexible methods, (4) involvement is early and continuous, (5) efforts result in action, and (6) they seek to build trust among participants. Particular attention to the situational context of actions and decisions helps to determine the relevance of adaptive management for individuals in these settings.
\end{abstract}

KEY WORDS: adaptive management, citizen-agency interactions, civic science, flexibility, forest management, inclusion, innovation, propositional analysis, public involvement. 


\section{INTRODUCTION}

Lee's (1993) analysis of adaptive management recognized the shortcomings surrounding public policy implementation and advocated a reliance not only on traditional science for managing ecosystems, but also on civic science. He noted that there are dilemmas implicit in pursuing science in a political setting, asserting that our methods "should be irreducibly public in the way responsibilities are exercised ... open to learning from errors and profiting from successes" (1993:161). Although the concept of adaptive management is not new, nor is the need to involve people in the process, there is a gross lack of monitoring and evaluating citizen-agency interactions in adaptive systems. One reason is that social scientists are relative latecomers in the study of ecological systems and have only recently been asked to play a role along with the biological research community, largely because of the growing recognition that decisions about these resources are eventually made in the sociopolitical arena.

Adaptive management experimentation in the Pacific Northwest region of the United States has revealed a strong interest among citizens for involvement in policy processes (see Shindler et al. 1996). Ehrenhaldt (1994: 6) put it more directly: "Nobody can fail to notice that in this decade, voters all over the country are looking for ways to inject themselves back into a government process that they feel the professional politicians have screwed up." Overall, there is an increasing appreciation that the nature of value-based ecological decisions requires new ways of thinking. As Rittel and Webber (1973) argued--and later Allen and Gould (1986)--natural systems are not only complex and complicated, but also their associated problems are "wicked." Although these problems will continue to require the input of sound science, measures that lead to improved conditions (as opposed to some kind of "final" solution) will require an increased sensitivity to the social, normative nature of the concerns to which adaptive management must be responsive (Stankey and Shindler 1997).

However, with little empirical study to guide adaptive public processes, there is also little room for measurement and evaluation of actions. Ostrom (1998) recognized the inability (and importance) of the social sciences to develop a theory explaining why cooperation in collective actions is highly variable. She argued that, although a scientific understanding of predictive behaviors is essential, so, too, is the need for institutions to facilitate more productive outcomes. Even if we could identify a set of predictive variables, testing and measuring outcomes is problematic. The difficulty thus far has been to get those on the management side of the equation to implement interaction strategies that can be tested and measured. Currently, an institutional stability and organizational culture that enables experimentation and learning among our natural resource agencies do not exist (NRC 1996). Resource professionals operate in a world of high expectations, but they often have a low level of understanding about constituent concerns, possess inadequate communication skills, and work in a climate of diminishing public trust (Blanha and Yonts-Shepard 1989). It is difficult to put a long-term plan for public engagement into action when the current climate is hostile and calls for immediate results.

Implicit in the current study is the belief that numerous factors influence the success of civic science and that many questions about the nature of these contributions still need to be addressed. Because early research efforts have been largely exploratory and primarily qualitative, we have undertaken an initial assessment of publicly oriented adaptive and ecosystem-based activities. This approach has enabled us to identify essential elements so that a framework for monitoring and evaluation could be developed. For a full description of this framework, see Shindler et al. (1999).

This summary paper is organized around six propositional statements. As with other social science examinations of adaptive/ecosystem-based approaches (e.g., Brunson 1993, Cortner et al.1996, Stankey and Shindler 1997), the use of propositions helps to guide problem identification and analysis. Our purpose here is to focus on critical questions about integrating citizens into adaptive solutions for ecological problems and, thus, to provide a basis for integrative research among disciplines. We summarize the important characteristics of citizen-agency interactions and describe contextual factors that influence particular outcomes.

\section{BACKGROUND}

Across the United States, resource agencies such as the Forest Service and the Bureau of Land Management have been struggling to find effective ways to include citizens in land planning and decision making. In the past, public involvement has often meant impersonal, linear forms of communication, such as newsletters or meetings at which administrators provide a one-way flow of information in an attempt to educate the public, often with limited success (e.g., Blahna and Yonts-Shepard 1989, Knopp and Caldbeck 1990, Cortner et al. 1998). In assessing federal land management agency attempts at public outreach, Jamieson (1994: 26) noted how ineffective this approach can be:

\footnotetext{
"Generally, programs that provide information are not very successful at improving understanding or changing
} 
behavior. Serious thought must be given to what it means to educate both the public and the policy-making community, as opposed to delivering brochures or reports. People tend to respond to stories, analogies, examples, and so on. Education is more likely to occur in the context of a personal relationship than in anonymous information provision."

As agencies turn toward ecosystem and adaptive management models of forest and rangeland stewardship, personnel are being called on to develop more meaningful relationships with citizens. Most often, adaptive management efforts are localized where it is easier to achieve cooperation among smaller groups of people, and where the jurisdictions are less bureaucratic than larger efforts concerned with more complex, broad-scale policies (NRC 1996). However, Thomas (1993) warned that these places are still subject to the "gladiators"--most notably the national (largely environmental) interest groups--who see little value in community-based approaches to their national agenda. However, adaptive management is about experimentation, failure, evaluation, and learning in identifiable, bounded settings. We first need to ascertain if these local sites-- often well below the radar screen of national causes and where the war won't be won or lost--are places where experimentation with social processes can be carried out.

In studies of public involvement research, Lawrence and Daniels (1996) described goals articulated by different researchers, practitioners, and citizens as falling into two distinct categories: (1) to arrive at decisions that better achieve resource management objectives, and (2) to come to decisions that enjoy increased public support. In the first case, the concern is with decisions being "objectively better" (Lawrence and Daniels 1996). In other words, the quality of decisions is improved, in part, by giving citizens the opportunity to provide relevant information (Cuthbertson 1983). For example, involving citizens can help to reveal issues of concern, provide an early warning system, tap local knowledge, identify ways to explore a range of alternatives, and explore consequences of the choices.

In the second case, decisions are perceived by participants to be "subjectively better" (Lawrence and Daniels 1996). As distrust of bureaucracies grows, citizens are increasingly demanding opportunities to participate in decisionmaking processes. Decisions that involve the public tend to evoke increased support, in part because people are more likely to accept the outcome of a process that they perceive to be fair (Knopp and Caldbeck 1990, Lauber and Knuth 1997). Alternatively, Creighton (1983) challenged the idea that a participative process bestows legitimacy on the context of the decisions made. He noted that if the people participating believe that their survival is at stake, "no amount of participation in the decision-making process will substitute for getting the answer out of the process which that group needs" (1983: 4). This view may be true at the polar ends, where people are highly ideological or their livelihoods depend on the outcome of a particular decision. Yet Lawrence et al. (1997) argued that the procedures used to come to decisions, not just the decisions themselves, are also important to people. Regardless of outcomes, failure of procedures to meet societal norms of fairness are likely to result in disaffection. Thus, the opportunity for citizens to participate may not be sufficient to insure public acceptance of decisions, but it does seem to be a necessary component.

\section{RESEARCH APPROACH}

To identify important elements of citizens' interactions with resource agencies, we performed a cross-case analysis of qualitative studies, particularly those involving adaptive or ecosystem-based planning processes. Synthesis of qualitative research has been acknowledged as a way a to build theory through induction and interpretation (Noblit and Hare 1988). The primary purpose of this form of evaluation is not causal determination or prediction. Rather, it seeks to identify social patterns and extrapolate lessons learned into findings useful for making decisions (Patton 1990). The emphasis is on illumination and understanding, particularly the contextual elements that influence outcomes. These methods have been tested in a variety of resource situations (e.g., Tilney and Riordan 1988, Chew 1989) and seem especially well suited for generating insights about the processes of interactive learning and decision making that form the basis of adaptive management applications.

\section{PROPOSITIONS FOR INTEGRATING CITIZENS IN ADAPTIVE MANAGEMENT}

An often-cited problem with learning how to conduct public processes is that every community is different and each situation is unique (Shindler and Neburka 1997). However, our analysis indicates that (1) common characteristics exist and can be clearly expressed, and (2) identifying contextual factors contributes to our understanding of successes and failures. Still, solutions are often situational and can depend on such variables as who participates in the process. Those most readily affected by a management action probably will be first to respond, usually based on how the action affects the status quo (e.g., their personal property, traditional economies, or highly-valued places). A basic premise in our analysis is that public land managers need to account for situational factors and give legitimacy to people's first reactions. 
From our analysis, we developed the six propositional themes that follow. These propositions are meant to elicit further questions, examination, and discourse; as an evaluative tool, they help to identify barriers to effective implementation of adaptive management and can help to generate actions to overcome these barriers. The propositions are intended to be tested and may ultimately prove more valuable as reference points in future investigations.

\section{Proposition 1: Open and inclusive public processes enjoy increased support.}

Public involvement is usually considered more successful if the processes employed include all affected parties and aim for broad representation (e.g., FEMAT 1993, Lawrence and Daniels 1996, Stankey and Shindler 1997). Knopp and Caldbeck (1990) observed that having an open, easily accessible program in which citizens are encouraged to speak up is important, because we cannot simply assume that volunteer organizations or public interest groups will adequately or fairly represent the total spectrum of public values. Because "there is no absolute standard by which to determine whether a fair balance has been reached" (Knopp and Caldbeck 1990: 14), having a variety of mechanisms for people to express themselves is essential to include various segments of the population who have differing abilities to participate.

The notion of inclusiveness begs the question of how "inclusive" decision-making processes actually need to be. Social scientists have observed that broad representation may not be an essential criterion for public involvement: "In a democracy, participation is voluntary and therefore is not expected to be representative of all segments of the general public" (Cuthbertson 1983: 102). The issue, then, is not whether all groups are represented, but whether those that are affected by, or are interested in, the outcome of a decision are given the opportunity to participate. Creighton (1983) challenged the idea that lack of participation by a significant social group is a sign of failure of a public involvement program. He acknowledged that people might not be involved because they are not fully aware of their self-interest in an issue, but he asserted that it could equally be argued that people are aware and simply choose to focus their energies on other priorities. Thus, Cuthbertson (1983) argued that the inclusiveness issue may be related more to the quality than to the magnitude of participation.

In an institutional analysis of adaptive management, The National Research Council (NRC 1996:340) summed up the essence of an experimental model that includes monitoring social processes: "Such a design will have no life unless those who are governed by it take a role in the processes of design and institutional reform." Curtis et al. (1995) acknowledged this view in citing inadequate representation of community interests as a key factor in why early attempts of the Australian Landcare policy failed. Paehlke and Torgerson (1990) were even more explicit, observing that local citizens have a direct, personal interest in uncovering problems and, thus, are often able to bring intensive, detailed knowledge of specific conditions to the analysis.

\section{Proposition 2: Skilled leadership and interactive forums contribute to long-term relationships among participants.}

To combat the growing ambivalence toward bureaucratic institutions, adaptive management will require leadership that is viewed as sincere, open, and honest. For example, Yaffee and Wondolleck (1997) found that people identified U.S. Forest Service collaboration efforts as successful when dedicated, open-minded individuals were willing to try more innovative approaches suited to a particular community's circumstances. Productive interactions usually begin with agency staff who understand the need to speak the public's language and learn about citizen's concerns and ideas, rather than simply trying to educate people about agency programs (Magill 1991, Brunson 1992).

However, skilled leadership in public outreach is rare among today's natural resource agencies. Many effective public processes can be traced to the presence of one or two agency individuals who are not just good leaders, but also demonstrate genuine interpersonal skills. Wondolleck and Yaffee (1997) found that failed collaborative efforts were often associated with the loss of a key person, when no one with similar skills was available to take over. Wesley (1995) noted it is difficult to institutionalize leadership and, thus, productive collaborations. This may be particularly true when resource managers are placed in an outreach role without adequate attention to whether they possess the requisite skills (Blahna and Yonts-Shepard 1989).

Today, the roles that agency personnel are being asked to play are much different than in the past, when citizens' involvement was minimal and scientific and technical expertise were key. Social values are at the root of many of our environmental conflicts, but managers are traditionally unprepared to deal with value-laden questions (Magill 1991) or to facilitate civic discourse about difficult choices (Goergen et al. 1995). Magill (1991) cited several typical shortcomings in resource professionals that contribute to the problem. First is an attitude of "we know best," in which professionals doubt the validity of public input and feel that the public lacks sufficient knowledge. Second is a feeling that resource professionals are above politics. Rarely did anyone first enter the field because they wanted to get their hands dirty in the political arena. Third is the use of technical jargon, which discourages the public's 
expression of personal values when presenting views about resource management. In contrast to a resource professional's (technical) response to a situation, a citizen's reaction may be emotional and expressed much differently. Agency personnel need to recognize these differences--and the legitimacy of citizens' responses based on feelings--in order for effective communication and public involvement to occur (Daniels 1997).

It is clear that agency staff with good interpersonal skills and willing attitudes are needed in positions where public contact is essential. However, even without formal training, demonstrating basic communication skills and a commitment to constituents often goes a long way. For example, Shindler and Neburka (1997) found that citizens preferred leaders who were seen as regular, honest people rather than polished professional facilitators. McCool et al. (1986) noted that this same genuine communication style often resulted in better understanding of natural resource issues, increased support for decisions, and greater ownership in a project by the public.

Good leaders have long known the two fundamental organizing strategies for public involvement: defining roles and setting good objectives. In evidence, Shindler and Neburka (1997) found that agency-citizen groups were much more successful when the purpose for meeting was defined and an anticipated end product was identified at the outset. They also noted that other basic attributes contributed to productive, on-going relationships including (1) groups in which the decision maker had a regular presence, (2) groups in which citizens thought they had been provided with the most current and reliable information, and (3) the simple "care and feeding" of participants, such as advanced distribution of meeting materials, definitions of complex terminology, prompt and direct answers to questions by the most qualified staffers, and even snacks at long meetings. Wherever these conditions existed, participants believed that their work was important and was taken seriously by the agency.

There appears to be a common message in these ideas, one that was recognized by both agency and citizen participants: "basic organizational skills, attention to detail, commitment to constituents, and good leadership--all things that people normally expect from our natural resource agencies--often mean the difference between success and frustration" (Shindler and Neburka 1997: 19). Jamieson (1994:27-28) focused the leadership accountability for action as the need to develop competency within organizations (e.g., the U.S. Forest Service) as well as in the communities where interactions take place:

"In the bad old days, there was a tendency for government agencies to dictate policy to citizens. These days, there is a tendency for citizens to try to dictate policy to government agencies. There is an admission price for engaging in public dialogue. Part of the price is purely formal: to treat others with respect, to be sympathetic to alternative points of view, to strive for impartiality, and so on. Part of the admission price also involves knowing something substantive about the issues: the relevant science, the economics, the values and interests that are at stake, and so on. People do not come with a ready-made ability to engage in a constructive, deliberative dialogue. The Forest Service should do what it can to develop its own competence for engaging in this dialogue, but it also should contribute to developing the competence of those with whom it engages. Only then will the turn toward public participation be mutually educational."

\section{Proposition 3: Innovation and flexibility improve the quality of decisions.}

Flexibility in citizenagency interactions seems particularly relevant in the context of adaptive management. For federal agencies, being flexible often means straying from traditional approaches and having the freedom to solve local problems and serve local priorities. For example, Shindler and Neburka (1997) found that, in local communities, success is often measured by the extent to which their own ideas and concerns are given serious consideration and the agenda is not driven by federal agency politics or national debates. However, citizens in these forest communities described a more typical approach as the "three I's of federal public involvement: Inform the locals, solicit their Input, then Ignore them."

In our society, in which we value rationality and empirical science, often only those values that can be empirically measured are counted as "real." But a paradox exists: those social values that are the most difficult to measure and define are the very ones that appear to be of increasing importance (FEMAT 1993). As a consequence, it is unlikely that we can solve the natural resource debate by simply counting better. The freedom to attempt innovative public involvement strategies seems essential to making adaptive management work.

Do our natural resource institutions possess the capacity to capture the potential of adaptive management? Walters (1997) revealed a pessimistic evaluation of previous adaptive management attempts. Among a number of specific reasons, he cited monitoring, lack of long-term commitment, inadequate funding, and a collection of "management difficulties" he articulated as risk aversion, inability to admit failure, and perceived threats to professional interests. Gunderson et al. (1995) were also critical, noting a disconnection between knowledge and action. When action fails to contribute to knowledge, we lose the core output of the adaptive management process. At the same time, Yaffee and Wondolleck were able to document a number of success stories in which the Forest Service connected with the public in "new ways" (e.g., Yaffee and Wondolleck 1997). At issue, however, was the ability for these efforts to be sustained in any meaningful way. 
Clearly, the capacity question is central to effective implementation of progressive styles like adaptive management. Currently, few organizational incentives exist for such behavior. In assessing the peril and promise of federally designated adaptive management areas in the Pacific Northwest, Stankey and Shindler (1997) found that agency personnel were operating in an atmosphere of uncertainty. They cited a lack of long-term funding, ill-defined administrative direction and support, and a hesitancy about innovation as all working against the "can-do" spirit that characterizes the natural resource professions. Additionally, citizens and field personnel voiced frustration with the prescriptive "one size fits all" policies that came from the top-down management styles of the resource agencies (Stankey and Shindler 1997). Cortner et al. (1996) made similar judgments in a problem analysis of federal institutional barriers; they asserted that implementing adaptive approaches will require both internal changes and a break from traditional management styles. The freedom to try new ideas will require a major shift in management culture toward one that encourages risk and accepts the occurrence of failures.

\section{Proposition 4: Early and continuous involvement improves public understanding of the issues and managers understanding of participant perspectives.}

As required by legislation (NEPA, RPA, and NFMA), public participation is an integral part of planning and decision making, not a separate planning device. As early as 1971, Bolle noted that the involvement emphasis is on process. He argued that the question is not in which steps the public should participate, but that it must be within the entire planning process if any benefits are to accrue. When the public is consulted in a piecemeal fashion, or only late in the planning process, it suggests that the agency has already made the decision, or worse yet, that it has something to hide. Little public ownership evolves in such decisions.

In practice, federal agencies have often been slow to invite the public into planning activities (Cortner et al. 1998). Through habit, reluctance, or lack of understanding of the benefits, staff usually have not engaged their publics soon enough to fully incorporate citizens' ideas or to gain their trust in management decisions. Likewise, regular follow-up with constituents often lags (or is non-existent), adding to what participants in federal forest management in southeast Alaska have termed the "illusion of public involvement" (Shindler 1997). The need to bring publics in early, however, is secondary to what a Canadian research team termed "up-front thinking" (Delli Priscoli and Homenuck 1990). They argue that before opening the door to citizens, agencies should first invest internal resources in strategically planning their public processes. For example, managers should ask themselves:

1) How will decisions be made?

2) What do we hope to accomplish with the public?

3) What does the public need to know to participate effectively?

4) Who is "the public" for this issue?

5) What special circumstances exist?

In an empirical study of 10 federal adaptive management sites, Shindler and O'Brian (1998) found this level of strategic thinking severely lacking. They noted that carefully thinking through the public involvement process in advance helps an agency to avoid costly problems later when citizens become actively engaged. It also is a good way to insure that staff are clear on the public involvement concept.

\section{Proposition 5: Efforts that result in tangible outcomes demonstrate accountability and build ownership among those involved.}

Although citizens value the opportunity to participate in planning activities, they have limited resources and energy to do so. People not only want to know what their role is, but also expect that something will actually result from their efforts (Shindler et al. 1999). Researchers agree that an essential, overriding principle in any public process is that citizens should be able to see evidence that their comments or suggestions are actually incorporated into decisions (e.g., Benfield 1985, Blahna and Yonts-Shepard 1989, Lyden et al. 1990). When people are able to trace the steps used in coming to a decision, understanding improves and they are more likely to support the outcome.

A distinction is made between simply listening to the public vs. actually allowing them to influence the land use or resource allocation. This distinction is hard to establish. As long as the ultimate decisions, the trade-offs, occur in a black box, no one on the outside can be sure that the public has any influence (Knopp and Caldbeck 1990:14).

Thus, people's participation becomes more meaningful when they can see actual on-the-ground progress: completion of a project, improvement in site quality, or the provision of a new public service (Yaffee and Wondolleck 1997). It follows that citizens also want to know that someone within the agency is accountable for a plan or a project's implementation. They want to see the responsible staffer make good on what they built together 
(Shindler and Collson 1998). Nothing speaks louder to people than seeing their efforts turn into action. Ostrom (1990) acknowledged that achieving these positive outcomes in the complex, conflict-ridden natural resource environment requires considerable trial and error among participants.

From an organizational standpoint, staff empowerment to achieve results often depends on internal support from supervisors and co-workers. The clarification of roles and agency commitments is particularly important to front-line personnel who are being asked to engage the public. Nowadays, these staffers cannot make important decisions on their own, and when they do, the public may not believe them anyway. Wondolleck and Yaffe (1997) called for agency actions that enable personnel to develop constructive community relations and encourage them to experiment with adaptive public strategies.

\section{Proposition 6: Incorporating citizens' ideas and experiences in decisions builds trust in natural resource institutions.}

The final theme in developing positive citizen-agency interactions involves the need to re-build public trust in land management agencies. The U.S. Forest Service, for example, was once hailed as a bureaucratic superstar, possessing a remarkable ability to sense changing public priorities and to adapt its mission to meet those demands (Clarke and McCool 1985). More recently, however, the agency has had serious credibility problems with its public image (e.g., Yaffee 1994, Cortner et al. 1998), leading to a constituent disconnect at both the local and national levels.

Issues of trust and credibility are of particular concern for managers in adaptive management experiments. Communications with citizens do not occur in isolation from one another. Not only is every public interaction influenced by a social history tied to previous encounters, but managers are part of a larger institutional culture that influences their ability to provide effective leadership on the local level. Interpersonal trust--characterized in part by an individual being able to believe what another says and think that the other person is interested in joint gains, not just personal gains--is essential to the functioning of groups and, ultimately, to decision making. But trust in individual forest managers is complicated by the public's view of the large federal bureaucracies for which these managers work. Although community members want to trust "Joe" to do the right thing on the local forest, they may not trust his agency to allow him to do so (Shindler and O'Brian 1998). However, empirical research from adaptive management settings suggests that there may be means to approach this problem. Steel et al. (1998) found that members of rural communities were more likely to trust the information provided by local resource managers, whereas urban residents preferred information from university scientists. Such findings may be useful in guiding public outreach activities across settings.

Building public trust is difficult; it takes great patience, requiring many opportunities for parties to interact, to get to know one another, and for participants' voices to be heard. At the most basic level, the experiences of getting to know the "other side" provide beneficial cumulative outcomes for all involved (Yaffee and Wondolleck 1997, Shindler et al. 1999). Of course, the process of restoring public confidence involves a long-term commitment. In forest communities, Shands (1992:364) recognized the resulting benefits:

"For public agencies, the real product of planning is not the plan, but an enduring relationship with the agency's constituents, clients, and customers. Properly done, the benefits of public involvement will continue long after a plan is complete or the decision is made."

\section{CONCLUSION}

Although each of these propositions provides various insights to effective citizen-agency interactions, the worth of any synthesis is in its meaning and value to those involved. Patton (1990) recognized that qualitative evaluations do not necessarily allow the prioritization of factors, because the factors work together in such a way that no one is primary or sufficient. Instead, each makes a critical contribution to an integrated, effectively functioning system. Identifying contributing elements begins the process of improving program implementation, monitoring responses and behaviors, and evaluating outcomes: all essential features of adaptive management.

In addition to identifying important factors for interaction, the research also suggests that there are large-scale goals, or desired results, for public participation. Collectively, the specific characteristics seem to serve as a means for accomplishing overall goals. For example, open and inclusive interactions in a singular planning process also help to build long-term relationships and are likely to result in decisions that enjoy increased public support. On-site, practitioners will employ strategies for accomplishing a particular project; however, in the overall adaptive management context, how these single actions contribute to the broader, overarching goals for citizen interactions is the true payoff. Agency relationships with citizens are shaped largely by the cumulative nature of numerous contacts and exchanges that occur over the long term.

In summary, findings from this study lead us to agree with Wondolleck and Yaffee's (1997) view that numerous 
factors contribute to the endurance of successful interactions. Their continuing research on successful public partnerships indicates that trusting relationships are more likely to be sustained where there is continuity in personnel and philosophy, evidence of agency commitment, a focus for group actions, and a mechanism in place to maintain communication. The current study also suggests that agencies can help to sustain productive interactions by being flexible, by placing value on citizen's ideas, and by supporting and rewarding innovative experimentation. In adaptive management settings, it is particularly important that managers also pay attention to the circumstances in which events occur (Shindler et al. 1999). This contextual information is useful because it is about specific places and actions, and describes the details that contribute to particular outcomes. Most often, these are the things that prompt citizens to become involved in the first place. Accounting for this context helps us to understand people's motivations and the relevance of adaptive management activities in people's lives.

\section{RESPONSES TO THIS ARTICLE}

Responses to this article are invited. If accepted for publication, your response will be hyperlinked to the article. To submit a comment, follow this link. To read comments already accepted, follow this link.

\section{Acknowledgments:}

The authors would like to thank Peter List of the Philosophy Department at Oregon State University for his thoughtful comments during the preparation of this paper. This research was supported by the People and Natural Resources Program of the Pacific Northwest Research Station, USDA Forest Service.

\section{LITERATURE CITED}

Allen, G. M., and E. M. Gould. 1986. Complexity, wickedness, and public forests. Journal of Forestry 84(4):20-23.

Benfield, F. K. 1985. The Forest Service: can it learn to listen? Environment 27(7): 4-5, 44.

Blahna, D. J., and S. Yonts-Shepard. 1989. Public involvement in resource planning: toward bridging the gap between policy and implementation. Society and Natural Resources 2: 209-227.

Bolle, A. W. 1971. Public participation and environmental quality. Natural Resources Journal 11(3): 497-505.

Brunson, M. 1992. Professional bias and public perspectives. The Consortium for Social Values of Natural Resources Newsletter. Winter:8-9. USDA Forest Service, Pacific Northwest Research Station, Seattle, Washington, USA.

. 1993. "Socially acceptable" forestry: what does it imply for ecosystem management? Western Journal of Applied Forestry 8(4):116-119.

Chew, S. T. 1989. Agroforestry projects for small farmers. U.S. Agency for International Development Evaluation, Special Study Number 59. Washington, D.C., USA.

Clarke, J. N., and D. McCool. 1985. Staking out the terrain. State University of New York Press, Albany, New York, USA..

Cortner, H. J., M. A. Shannon, M. G. Wallace, S. Burke, and M. A. Moote. 1996. Institutional barriers and incentives for ecosystem management: a problem analysis. U.S. Forest Service General Technical Report

PNW-GTR-354. Pacific Northwest Research Station, Portland, Oregon, USA.

Cortner, H. J., M. Wallace, S. Burke, and M. Moote. 1998. Institutions matter: the need to address the institutional challenges of ecosystem management. Landscape and Urban Planning 40:159-166.

Creighton, J. L. 1983. An overview to the research conference on public involvement and social impact assessment. Pages 1-10 in M. W. Garcia and J. D. Priscoli, editors. Public involvement and social impact assessment. Westview Press, Boulder, Colorado, USA.

Curtis, A., J. Birckhead, and T. DeLacy. 1995. Community participation in Landcare policy in Australia. Society and Natural Resources 8(5):415-430.

Cuthbertson, I. D. 1983. Evaluating public participation: an approach for government practitioners. Pages 101-109 in G. A. Daneke, M. W. Garcia, and J. D. Priscoli, editors. Public involvement and social impact assessment. Westview Press, Boulder, Colorado, USA. 
Daniels, S. E. 1997. Human reactions to large-scale wildfires: contrasting the responses of U.S. Forest Service personnel and the general public to the 1994 Wenatchee fires. (Draft report). Oregon State University Press, Corvallis, Oregon, USA.

Delli Priscoli, J., and P. Homenuck. 1990. Consulting the publics. Pages 67-80 in R. Lang, editor. Integrated approaches to land management. Banff Centre School of Management, Alberta Energy and Natural Resources, Edmonton, Alberta, Canada.

Ehrenhaldt, A. 1994. Let the people decide between spinach and broccoli. Governing 7(10):6-7.

FEMAT (Forest Ecosystem Management Assessment Team). 1993. Forest ecosystem management: an ecological, economic, and social assessment. U.S. Government Printing Office, Washington, D.C., USA.

Goergen, M. T., D. W. Floyd, and P. G. Ashton. 1995. An old model for building consensus and a new role for foresters. Journal of Forestry 95(1): 8-12.

Gunderson, L. H., C. S. Holling, and S. Light, editors. 1995. Barriers and bridges to the renewal of ecosystems and institutions. Columbia University Press, New York, New York, USA.

Jamieson, D. 1994. Problems and prospects for a Forest Service program in the human dimensions of global change. Pages 23-28 in Proceedings of Breaking the Mold: Global Change, Social Responsibility, and Natural Resource Policy Workshop, 1-3 May, Monterey, California. Oregon State University Press, Corvallis, Oregon, USA.

Knopp, T. B., and E. S. Caldbeck. 1990. The role of participatory democracy in forest management. Journal of Forestry 88(5): 13-18.

Lauber, T. B., and B. Knuth. 1997. Fairness in moose management decision making: the citizen's perspective. Wildlife Society Bulletin 25(4):776-787.

Lawrence, R. L., and S. E. Daniels. 1996. Public involvement in natural resource decision making: goals, methodology, and evaluation. Forest Research Laboratory Publication, Oregon State University, Corvallis, Oregon, USA.

Lawrence, R. L., S. E. Daniels, and G. H. Stankey. 1997. Procedural justice and public involvement in natural resource decision making. Society and Natural Resources 10: 577-589.

Lee, K. 1993. Compass and gyroscope. Island Press, Washington, D.C., USA.

Lyden, F. J., B. W. Twight, and E. T. Tuchmann. 1990. Citizen participation in long-range planning: the RPA experience. Natural Resources Journal 30(1): 123-138.

Magill, A. W. 1991. Barriers to effective public interaction: helping natural resource professionals adjust their attitudes. Journal of Forestry 89(10):16-18.

McCool, S. F., J. L. Ashor, and G. L. Stokes. 1986. An alternative to rational-comprehensive planning: transactive planning. In Proceedings of the National Wilderness Research Conference: Current Research, Fort Collins Colorado. USDA Forest Service Intermountain Research Station, Ogden, Utah, USA.

NRC (National Research Council). 1996. Upstream: salmon and society in the Pacific Northwest. National Academy Press, Washington, D.C., USA.

Noblit, G., and R. D. Hare.1988. Meta-ethnography: synthesizing qualitative studies. Sage Publishers, Newbury Park, California, USA.

Ostrom, E. 1990. Governing the Commons: the evolution of institutions for collective action. Cambridge University Press, New York, New York, USA.

. 1998. A behavioral approach to the rational choice theory of collective action. Presidential Address, American Political Science Association, 1997. American Political Science Review 92(1):1-22.

Paehlke, R., and D. Torgerson. 1990. Managing Leviathan: environmental politics and the administrative state. Broadview Press, Ontario, Canada.

Patton, M. P. 1990. Qualitative evaluation and research methods. Sage Publishers, Newbury Park, California, USA.

Rittel, H. W., and M. M. Webber. 1973. Dilemmas in a general theory of planning. Policy Science 4:155-169.

Shands, W. E. 1992. Public involvement, forest planning, and leadership in a community of interests. Pages 
360-367 in Proceedings of American Forestry: An Evolving Tradition. Society of American Foresters' National Convention. Richmond, Virginia, USA.

Shindler, B. 1997. Citizen values and participation in the Tongass National Forest debate. Pages 165-172 in B. Steel, editor. Public lands management in the west. Praeger Press, Westport, Connecticut, USA.

Shindler, B., K. A. Cheek, and G. H. Stankey. 1999. Monitoring and evaluating citizen-agency interactions: a framework developed for adaptive management. U.S. Forest Service General Technical Report PNW-GTR99-452. Pacific Northwest Research Station, Portland, Oregon, USA.

Shindler, B., and P. Collson. 1998. Assessing public preferences for ecosystem management practices. Pages 161-174 in D. Soden and B. L. Lamb, editos. Ecosystem management: a social science perspective. Kendall/Hunt, Dubuque, Iowa, USA.

Shindler, B., and J. Neburka. 1997. Public participation in forest planning: eight attributes of success. Journal of Forestry 95(1):17-19.

Shindler, B., and K. O'Brian. 1998. Citizen survey of public involvement in adaptive management. U.S. Forest Service Research Report PNW 94-0584. PNW Research Station, People and Natural Resources Program, Corvallis, Oregon, USA.

Shindler, B., B. Steel, and P. List. 1996. Public judgments of adaptive management. Journal of Forestry 94(6):5-12.

Stankey, G. H., and B. Shindler. 1997. Adaptive Management Areas: achieving the promise, avoiding the peril. U.S. Forest Service General Technical Report PNW-GTR-394. Pacific Northwest Research Station, Portland, Oregon, USA.

Steel, B. S., B. A. Shindler, and M. Brunson. 1998. Social acceptability of ecosystem management in the northwest. Page 147-160 in D. L. Soden, B. L. Lamb, and J. R. Tennert, editors. Ecosystems management. Kendall/Hunt, Dubuque, Iowa, USA.

Thomas, J. W. 1993. Turmoil in transition: forest management approaches on the public lands. Starker Lectures Presentation Series, College of Forestry, Oregon State University. Corvallis, Oregon, USA.

Tilney, J. S., and J. Riordan. 1988. Agricultural policy analysis and planning: a summary of two recent analyses of A.I.D.-supported projects worldwide. U.S. Agency for International Development Evaluation, Special Study Number 55. Washington, D.C., USA.

Walters, C. J. 1997. Challenges in adaptive management of riparian and coastal ecosystems. Conservation Ecology [online]1:1. Available at URL: http://www.consecol/org/vol1/iss2/art1.

Wesley, F. 1995. Governing design: the management of social systems and ecosystems management. Pages 391-427 in L. H. Gunderson, C. S. Holling, and S. S. Light, editors. Barriers and bridges to the renewal of ecosystems and institutions. Columbia University Press, New York, New York, USA.

Wondolleck, J. M., and S. L. Yaffee. 1997. Sustaining the success of collaborative partnerships: revisiting the building bridges cases. U.S. Forest Service Research Report PNW 95-0728. Pacific Northwest Research Station, Portland, Oregon, USA.

Yaffee, S. L., and J. Wondolleck. 1997. Building bridges across agency boundaries. Pages 381-396 in K. A. Kohm and J. F. Franklin, editors. Creating a forestry for the 21st century. Island Press, Washington, D.C., USA.

\section{Address of Correspondent: \\ Bruce Shindler \\ Department of Forest Resources \\ Oregon State University \\ Corvallis, Oregon 97331 USA \\ Phone: (541) 737-3299 \\ Fax: (541) 737-3049 \\ shindleb@ccmail.orst.edu}

*The copyright to this article passed from the Ecological Society of America to the Resilience Alliance on 1 January 2000. 
Home | Archives | About | Login | Submissions | Notify | Contact | Search 